\title{
Flatulence-causing galactooligosaccharides of Phaseolus coccineus L. and Phaseolus vulgaris $\mathrm{L}$.
}

\author{
RYSZARD KOSSON
}

Department of Processing and Freezing, Research Institute of Vegetable Crops, 22 Lipca 1/3, 96-00 Skierniewice, Poland

(Received: March 15, 1988. Accepted: May 18, 1988)

\begin{abstract}
Phaseolus coccineus beans were assayed for the presence of raffinose and stachyose in whole seeds and in the morphological parts of the seed: cotyledon, hypocotyl and hull. The quantitative composition of the galactooligosaccharides of Ph. coccineus was compared with Ph. vulgaris seeds. The major galactooligosaccharide of Ph. coccineus seeds is stachyose. Another galactooligosaccharide, verbascose, was present in Ph. coccineus seeds in very low amounts $(0.04 \%)$. The highest concentrations of raffinose and stachyose were found in the hypocotyl, $1.11 \%$ and $7.48 \%$, respectively. The hull contained the lowest quantities of stachyose and only traces of raffinose.
\end{abstract}

Key words: Phaseolus coccineus, Phaseolus vulgaris, seed, cotyledon, hypocotyl, hull, galactooligosaccharide content

\section{INTRODUCTION}

The galactooligosaccharides of the raffinose family of sugars (raffinose, stachyose and verbascose) from legume seeds have been known as one of the important contributors to flatus in humans when ingested (Murphy et al. 1972, Cristofaro et al. 1973). This is primarily due to the lack of the hydrolytic enzyme, alpha-galactosidase in the human gastrointestinal tract (Gitzelmann and Aurricchio 1965).

The predominance of a particular oligosaccharide seems to depend on the type of legume. For example, verbascose is the major oligosaccharide in the seeds of Phaseolus mungo, Cicer arietinum, Cajanus cajan, Phaseolus aureus and Vicia faba, whereas stachyose is the major oligosaccharide in Pisum sativum, Phaseolus vulgaris, Lens esculenta, Glycine max and Dolichos sinensis. Raffinose is present in moderate to low amounts in most legumes. Ajugose is the other higher molecular weight oligosaccharide of the raffinose family of 
sugars, which is present in small amounts in Pisum sativum and Lupinus albus (Reddy et al. 1984).

Most species of the Phaseolus genus have already been studied for the presence of those sugars in seeds; for example, Phaseolus vulgaris (Iyer et al. 1980), Phaseolus aureus (Naivikul and D'Appolonia 1978), Phaseolus mungo (R a o and Belavady 1978), Phaseolus lunatus (Harding e et al. 1965), Phaseolus chrysanthos (T a nusi et al. 1972). However, no papers were found in the available literature on the sugars of the raffinose family in the seeds of Phaseolus coccineus (Phaseolus multiflorus).

For this reason, the present paper describes the extraction and quantitative determination of raffinose and stachyose in whole seeds of Phaseolus coccineus. The distribution of these sugars in the cotyledon, hypocotyl and hull was estimated as well. The contents of raffinose and stachyose in Phaseolus coccineus seeds were compared with Phaseolus vulgaris seeds.

\section{MATERIALS AND METHODS}

PLANT MATERIAL

The seeds of the runner bean cultivar Piękny Jaś (Ph. coccineus) and 4 local populations of semi-runner bean ( $P h$. coccineus), originating from SHRO Snowidza, Kasiłan, Tyszowce and Kraśnik, were assayed for the presence of raffinose and stachyose. Verbascose was determined in semi-runner bean populations from SHRO Snowidza. Cotyledons, hypocotyls and hulls were isolated from seeds of Piękny Jaś cultivar and an analysis of galactooligosaccharides was performed. Four cultivars and 4 breeding lines of Phaseolus vulgaris were selected for raffinose and stachyose analysis in seeds.

\section{EXTRACTION AND SILYLATION}

The air-dry bean seeds were homogenized in a Tecator blender to obtain flour of $0.42-0.25 \mathrm{~mm}$. The galactooligosaccharides were extracted from the beans by refluxing a $10 \mathrm{~g}$ sample for half an hour with $100 \mathrm{~cm}^{3}$ of $80 \%$ ethanol. Extracts were cooled, centrifuged and transfered to $100 \mathrm{~cm}^{3}$ volumetric flasks. A sample of $100-200 \mathrm{~mm}^{3}$ of supernatant was evaporated to dryness using a stream of air. Sugars were converted to their trimethylsilyl derivatives (TMS) by an injection of $100 \mathrm{~mm}^{3}$ of silylating mixture containing trimethylsilylimidazole and pirydine according to a previously described method (Kosson 1988).

\section{GAS LIQUID CHROMATOGRAPHY}

A Jeol JGC-1100 gas chromatograph with a flame ionization detector (FID) was used for the separation of the TMS derivatives of raffinose and stachyose. Glass columns $(1.5 \mathrm{~m} \times 3 \mathrm{~mm})$ were packed with $3 \%$ SE-30 on 
60/80 mesh Gas Chrom Q. Gas chromatography operating conditions were: carrier gas - argon; injector temperature $305^{\circ} \mathrm{C}$, detector oven temperature $305^{\circ} \mathrm{C}$, column temperature $270^{\circ} \mathrm{C}$, with programmed increase at $2^{\circ} \mathrm{C} \min ^{-1}$ to $305^{\circ} \mathrm{C}$.

\section{RESULTS AND DISCUSSION}

The results given in Table 1 show that Phaseolus coccineus seeds contained $0.29-0.51 \%$ raffinose and $2.29-2.50 \%$ stachyose. Both runner bean and semi-runner local populations belonging to the same species, Ph. coccineus, did not differ significantly in the stachyose contents, although the total galactooligosaccharides content was found to be higher in runner bean.

\section{Table 1}

Raffinose and stachyose content in Phaseolus coccineus whole seeds (\%)

\begin{tabular}{|l|c|c|c|}
\hline \multicolumn{1}{|c|}{ Ph. coccineus } & Raffinose (R) & Stachyose (S) & Sum (R+S) \\
\hline $\begin{array}{l}\text { Runner bean cultivar } \\
\text { Piękny Jaś }\end{array}$ & $0.51 \pm 0.01^{*}$ & $2.50 \pm 0.06$ & 3.01 \\
\hline Semi-runner local & & & \\
population from: & & & \\
Snowidza SHRO & $0.29 \pm 0.01$ & $2.42 \pm 0.10$ & 2.71 \\
Kasiłan & $0.33 \pm 0.00$ & $2.34 \pm 0.21$ & 2.67 \\
Tyszowiec & $0.30 \pm 0.00$ & $2.29 \pm 0.20$ & 2.59 \\
Kraśnik. & $0.30 \pm 0.01$ & $2.50 \pm 0.23$ & 2.80 \\
\hline
\end{tabular}

- Averages from five or three independent replicates \pm confidence limits at $p=0.95$ evaluated according to Dean and Dixon test.

There are no publications in the available literature concerning the galactooligosaccharides in $P h$. coccineus seeds; therefore, our results were compared to $P h$. vulgaris beans (Table 2). The raffinose and stachyose contents in both Ph. vulgaris and Ph. coccineus species were similar. Differences in the raffinose content between the analysed $P h$. vulgaris cultivars were nearly double and triple. The results obtained concerning to the raffinose and stachyose content in $\mathrm{Ph}$. vulgaris seeds are in agreement with those published in literature (Iyer et al. 1980, Reddy et al. 1984).

According to the data presented in Table 3, raffinose and stachyose are not regularly distributed in all parts of the $\mathrm{Ph}$. coccineus seed, the cotyledon, hypocotyl and hull. The highest concentration of raffinose and stachyose was found in the hypocotyl, $1.11 \%$ and $7.49 \%$ respectively. The hull contained only traces of raffinose and small quantity of stachyose. Cerning et al. (1975) 
Table 2

Raffinose and stachyose contents in Phaseolus vulgaris whole seeds (\%)

\begin{tabular}{|l|c|c|c|}
\hline \multicolumn{1}{|c|}{ Ph. vulgaris } & Raffinose (R) & Stachyose (S) & Sum (R+S) \\
\hline Cultivar & & & \\
Janina & $0.20 \pm 0.03$ & $1.85 \pm 0.26$ & 2.05 \\
Wiejska & $0.19 \pm 0.01$ & $1.94 \pm 0.08$ & 2.13 \\
Atut & $0.35 \pm 0.01$ & $2.57 \pm 0.21$ & 2.92 \\
Biała Wyborowa & $0.42 \pm 0.03$ & $2.04 \pm 0.15$ & 2.46 \\
\hline Breeding line & & & \\
IGE 900/82 & $0.20 \pm 0.00$ & $1.94 \pm 0.20$ & 2.14 \\
IGE 29/83 & $0.15 \pm 0.01$ & $1.94 \pm 0.06$ & 2.09 \\
IGE 1168/83 & $0.15 \pm 0.01$ & $2.16 \pm 0.16$ & 2.31 \\
IGE 1446/83 & $0.45 \pm 0.01$ & $1.86 \pm 0.34$ & 2.31 \\
\hline
\end{tabular}

investigated oligosaccharides in cotyledons (including germ) and hulls of Vicia faba seeds and stated that the hulls contained much less oligosaccharides than cotyledons; only traces of raffinose were present in the hulls. Vicia faba and $P h$. coccineus belong to the same family, Papilionaceae.

\section{Table 3}

Galactooligosaccharide content in cotyledon, hypocotyl and hull of Phaseolus coccineus seeds (\%)

\begin{tabular}{|l|c|c|c|}
\hline \multicolumn{1}{|c|}{ Part of seed } & Raffinose (R) & Stachyose (S) & Sum (R+S) \\
\hline Cotyledon & $0.40 \pm 0.03$ & $3.10 \pm 0.33$ & 3.50 \\
Hypocotyl & $1.11 \pm 0.18$ & $7.49 \pm 0.70$ & 8.60 \\
Hull & $0.06 \pm 0.00$ & $0.37 \pm 0.13$ & 0.43 \\
\hline
\end{tabular}

Only $0.04 \%$ of verbascose was found in $P h$. coccineus seeds of semi-runner bean (not shown in tables). A similar level of verbascose $-0.1 \%-$ was reported by Iyer et al. (1980) and Reddy et al. (1984) in Phaseolus vulgaris seeds.

\section{REFERENCES}

Cerning J., Saposnik A., Guilbot A., 1975. Carbohydrate composition of horsebeans (Vicia faba L.) of different origins. Cereal Chem. 52: 125-138.

Cristofaro E., Mottu F., Wuhrmann J. J., 1973. Study of the effect on flatulence of leguminous seeds oligosaccharides. Nestle Res. News 102-104.

Gitzelmann R., Aurricchio S., 1965. The handling of soy alpha-galactosides by a normal and galactosemic child. Pediatrics 36: 231-235. 
Hardinge M. G., Swarner J. B., Crooks H., 1965. Carbohydrates in foods. J. Amer. Diet. Ass. 46: 197-204.

Iyer V., Salunkhe D. K., Sathe S. K., Rockland L. B., 1980. Quick cooking of beans (Phaseolus vulgaris L): II. Phytates, oligosaccharides antienzymes. Qual. Plant. - Plant Foods Human Nutr. 30: 45-52.

K osson R., 1988. Optymalizacja niektórych parametrów analizy galaktocukrów gazotwórczych w fasoli metodą chromatografii gazowej. Bromat. Chem. Toksykol. (w druku).

Murphy E. L., Horsley H., Burr H. K., 1972. Fractionation of dry bean extracts which increase carbon dioxide egestion in human flatus. J. Agric. Food Chem. 20: 813-817.

Naivikul O., D’Appolonia B. L., 1978. Comparison of legume and wheat flour carbohydrates: I. Sugar analysis. Cereal Chem. 55: 913-918.

Ra o P. V., Belavady B., 1978. Oligosaccharides in pulses, varietal differences and effect of cooking and germination. J. Agric. Food Chem. 26: 316-319.

Reddy N. R., Pierson M. D., Sathe S. K., Salunkhe D. K., 1984. Chemical, nutritional and physiological aspects of dry bean carbohydrates. Food Chem. 13: 25-68.

Tanusi S., Kawamura S., Kasai T., 1972. Methods of determining carbohydrates of mature legume seeds. J. Jap. Food Nutr. 25: 38-41.

Galaktooligosacharydy gazotwórcze w nasionach Phaseolus coccineus L. i Phaseolus vulgaris $L$.

\section{Streszczenie}

Oznaczono skład ilościowy galaktooligosacharydów: rafinozy i stachiozy w całych nasionach oraz w liścieniach, hypokotylu i łusce nasion fasoli wielokwiatowej Phaseolus coccineus. Dla porównania oznaczono zawartość tych cukrów w nasionach odmian i linii hodowlanych Phaseolus vulgaris. Wykazano, że podobnie jak w nasionach $P h$. vulgaris, głównym galaktooligosacharydem w nasionach $P h$. coccineus jest stachioza. Inny z galaktocukrów - werbaskoza - jest obecny w nasionach $P h$. coccineus w bardzo małych ilościach $(0.04 \%)$. Największe stężenie stachiozy i rafinozy stwierdzono w hypokotylu, odpowiednio $7.48 \%$ i $1.11 \%$. Okrywa nasienna fasoli zawiera najmniejsze ilości stachiozy - w porównaniu z innymi częściami nasion - oraz tylko śladowe ilości rafinozy. 